\title{
The novel pterostilbene derivative ANK-199 induces autophagic cell death through regulating PI3 kinase class III/beclin 1/Atg-related proteins in cisplatin-resistant CAR human oral cancer cells
}

\author{
MIN-TSANG HSIEH ${ }^{1,4}$, HAO-PING CHEN ${ }^{5}$, CHI-CHENG LU ${ }^{6}$, JO-HUA CHIANG ${ }^{7}$, TIAN-SHUNG WU ${ }^{7}$, \\ DAIH-HUANG KUO ${ }^{8}$, LI-JIAU HUANG ${ }^{2}$, SHENG-CHU KUO $^{2}$ and JAI-SING YANG ${ }^{3}$ \\ ${ }^{1}$ School of Pharmacy, ${ }^{2}$ Graduate Institute of Pharmaceutical Chemistry and ${ }^{3}$ Department of Pharmacology, \\ China Medical University; ${ }^{4}$ Chinese Medicinal Research and Development Center, China Medical University Hospital, \\ Taichung 404; ${ }^{5}$ Department of Biochemistry, Tzu Chi University, Hualien 970; ${ }^{6}$ Department of Food Science \\ and Biotechnology, National Chung Hsing University, Taichung 402; ${ }^{7}$ Department of Chemistry, \\ National Cheng Kung University, Tainan $701 ;{ }^{8}$ Department of Pharmacy and Graduate Institute \\ of Pharmaceutical Technology, Tajen University, Pingtung 907, Taiwan, R.O.C.
}

Received March 6, 2014; Accepted May 2, 2014

DOI: $10.3892 / \mathrm{ijo} .2014 .2478$

\begin{abstract}
Pterostilbene is an effective chemopreventive agent against multiple types of cancer cells. A novel pterostilbene derivative, ANK-199, was designed and synthesized by our group. Its antitumor activity and mechanism in cisplatin-resistant CAR human oral cancer cells were investigated in this study. Our results show that ANK-199 has an extremely low toxicity in normal oral cell lines. The formation of autophagic vacuoles and acidic vesicular organelles (AVOs) was observed in the ANK-199-treated CAR cells by monodansylcadaverine (MDC) and acridine orange (AO) staining, suggesting that ANK-199 is able to induce autophagic cell death in CAR cells. Neither DNA fragmentation nor DNA condensation was observed, which means that ANK-199-induced cell death is not triggered by apoptosis. In accordance with morphological observation, 3-MA, a specific inhibitor of PI3K kinase class III, can inhibit the autophagic vesicle formation induced by ANK-199. In addition, ANK-199 is also able to enhance the protein levels of
\end{abstract}

Correspondence to: Professor Sheng-Chu Kuo, Graduate Institute of Pharmaceutical Chemistry, China Medical University, No. 91, HsuehShih Road, Taichung 40402, Taiwan, R.O.C.

E-mail:sckuo@mail.cmu.edu.tw

Dr Jai-Sing Yang, Department of Pharmacology, China Medical University, No. 91, Hsueh-Shih Road, Taichung 40402, Taiwan, R.O.C.

E-mail: jaisingyang@gmail.com

Key words: ANK-199, autophagic cell death, PI3 kinase class III, beclin 1, autophagy-related proteins, cisplatin-resistant CAR human oral cancer cells autophagic proteins, Atg complex, beclin 1, PI3K class III and LC3-II, and mRNA expression of autophagic genes Atg7, Atg12, beclin 1 and LC3-II in the ANK-199-treated CAR cells. A molecular signaling pathway induced by ANK-199 was therefore summarized. Results presented in this study show that ANK-199 may become a novel therapeutic reagent for the treatment of oral cancer in the near future (patent pending).

\section{Introduction}

Pterostilbene, a natural stilbenoid compound of phenolic phytoalexin analogue, is found in narra tree, grape and blueberries (Fig. 1A) (1-4). It possesses many different pharmacological and biologic activities, such as anticancer activity with low intrinsic toxicity (4-6), anti-inflammatory properties (7-9), anti-oxidative effect (2), regulation of neutrophil function $(10,11)$ and protection against free radical-mediated oxidative damage (12-14). The anticancer activity of pterostilbene has drawn the most attention among of them so far (1,4-6). As reported in previous studies, pro-apoptosis $(4,15,16)$, pro-autophagy (17-19), telomerase inhibition (20), DNA damage $(12,13,15)$, anti-angiogenesis $(21)$, anti-metastasis $(4,21)$ and immuno-stimulatory effects $(10,11)$ are possible mechanisms responsible for its anticancer activity.

Pterostilbene is able to induce apoptosis in many different cancer cell lines, such as pancreatic cancer cells $(22,23)$, breast cancer MCF-7 cells $(20,24,25)$, docetaxel-induced multiple drug resistance (MDR) lung cancer cells (26), osteosarcoma cells (27), prostate cancer PC-3 and LNCaP cells $(28,29)$, leukemia K562 cells $(30,31)$, MDR and BCR-ABL-expressing leukemia cells $(30,31)$, colon cancer cells $(32-34)$, hepatocellular carcinoma cells $(35,36)$ and 
A<smiles>COc1cc(/C=C/c2ccc(O)cc2)cc(OC)c1</smiles>

Pterostilbene<smiles>COc1cc(/C=C/c2ccc(OC(=O)C(CO)(CO)CO)cc2)cc(OC)c1</smiles>

ANK-199

4-(3,5-dimethoxystyryl)phenyl 3-hydroxy-2-(hydroxymethyl)-2-methylpropanoate

Figure 1. Chemical structures of (A) pterostilbene and (B) ANK-199.

gastric carcinoma cells $(7,15)$. On the other hand, it is also reported that autophagic death can be triggered by pterostilbene in leukemia HL60 (17) and MOLT4 cells (37), lung cancer cells $(18,32,38)$, colon cancer HT29 cells $(32)$, breast cancer MCF-7 cells (39), bladder cancer cells $(17,40)$ and vascular endothelial cells (41). In addition, pterostilbene is capable of inhibiting tumorigenesis and metastasis with minor toxicity in vivo $(4,22,38)$. It is safe in doses up to $250 \mathrm{mg} /$ day in human clinical trial, and deserves further investigation as a potential anticancer agent (42). A novel pterostilbene derivative, ANK-199, was therefore designed and synthesized by our group (Fig. 1B).

Chewing the mixtures of betel leaf and areca nut is a popular custom in many South and Southeast Asia countries. It is a high risk factor for oral cavity carcinoma $(43,44)$, and is the 4th most common cause of cancer death in Taiwanese males (45). Natural product with high anticancer activity and low toxicity, like pterostilbene, appears to be an ideal candidate to prevent or treat oral cancer, as it can directly contact with human oral mucosa without intravenous administration or surgery (22). The anti-oral cancer activity of pterostilbene derivative, ANK-199, was first investigated in this study. Both normal human oral cell lines and cisplatin-resistant CAR human oral cancer cell lines were used. Here, we report the cytotoxic effect and anticancer mechanism of ANK-199 in human oral cancer CAR cells.

\section{Materials and methods}

Chemicals and reagents. Dimethyl sulfoxide (DMSO), 3-methyladenine (3-MA), 3-(4,5-dimethylthiazol-2-yl)2,5-diphenyl-2H-tetrazolium bromide (MTT), monodansyl cadaverine (MDC), cisplatin, $\beta$-actin antibody, and Tween-20 were obtained from Sigma-Aldrich Corp. (St. Louis, MO, USA). Fetal bovine serum (FBS), L-glutamine, penicillin/ streptomycin, Dulbecco's modified Eagle's medium (DMEM), acridine orange (AO), and trypsin-EDTA were purchased from Life Technologies (Carlsbad, CA, USA). The primary antibodies (anti-Atg5, anti-Atg7, anti-Atg12, anti-Atg14, anti-Atg16L1, anti-beclin 1, anti-PI3K class III, anti-LC3-II, and anti-Rubicon) were obtained from Cell Signaling Technology (Danvers, MA, USA), and the horseradish peroxidase (HRP)-conjugated secondary antibodies against rabbit or mouse immunoglobulin for western blot analysis were obtained from Santa Cruz Biotechnology, Inc. (Santa Cruz, CA, USA). ANK-199 [4-(3,5-dimethoxystyryl)phenyl 3-hydroxy-2-(hydroxymethyl)-2-methylpropanoate] was synthesized by Dr Sheng-Chu Kuo.

Cell culture. The human oral cancer cell line CAL 27 was obtained from the American Type Culture Collection (ATCC, Manassas, VA, USA). CAR, a cisplatin-resistant cell line, was established by clonal selection of CAL 27 using 10 cycles of 1 passage treatment with $10-80 \mu \mathrm{M}$ of cisplatin followed by a recovery period of another passage. CAR cells were cultivated in DMEM supplemented with $10 \% \mathrm{FBS}, 100 \mu \mathrm{g} / \mathrm{ml}$ streptomycin, $100 \mathrm{U} / \mathrm{ml}$ penicillin, $2 \mathrm{mM}$ L-glutamine and $80 \mu \mathrm{M}$ cisplatin. Human normal gingival fibroblasts cells (HGF) and human normal oral keratinocyte cells (OK) were kindly provided by Dr TzongMing Shieh (Department of Dental Hygiene, China Medical University). HGF and OK cells were cultivated in DMEM as previously described for our study (45).

Cell viability and morphological examination. CAR cells $\left(1 \times 10^{4}\right.$ cells) in a 96-well plate were incubated with $0,25,50$, 75 and $100 \mu \mathrm{M}$ of ANK-199 for 24, 48 and $72 \mathrm{~h}$. For incubation with the autophagy inhibitor, cells were pretreated with 3-MA $(10 \mathrm{mM})$ for $1 \mathrm{~h}$, followed by treatment with or without ANK-199 (50 and $75 \mu \mathrm{M}$ ) for $48 \mathrm{~h}$. After washing the cells, DMEM containing MTT $(0.5 \mathrm{mg} / \mathrm{ml})$ of was added to detect viability as previously described (6). The cell viability was expressed as \% of the control. Cell morphological examination of autophagic vacuoles was determined utilizing a phase-contrast microscope $(46,47)$.

Observation of autophagic vacuoles by MDC and acidic vesicular organelles (AVO) with AO staining. CAR cells were seeded on sterile coverslips in tissue culture plates with a density of $5 \times 10^{4}$ cells/per coverslip. After $0,50,75 \mu \mathrm{M}$ of ANK-199 treatment for $24 \mathrm{~h}$, cells were stained with either $1 \mu \mathrm{g} / \mathrm{ml} \mathrm{AO}$ or $0.1 \mathrm{mM} \mathrm{MDC}$ at $37^{\circ} \mathrm{C}$ for $10 \mathrm{~min}$. The occurrece of autophagic vacuoles and AVO were immediately observed under fluorescence microscopy (Nikon, Melville, NY, USA) (46-48).

Autophagy assay by LC3B-GFP imaging and nuclear stain. The induction of autophagy was detected with the Premo ${ }^{\mathrm{TM}}$ Autophagy Sensor (LC3B-GFP) BacMam 2.0 kit (Molecular Probes/Life Technologies). CAR cells were seeded on sterile coverslips in tissue culture plates with a density of $1 \times 10^{4}$ cells/per coverslip. After CAR cells were transfected with LC3B-GFP in accordance with the manufacturer's protocol, 
cells were treated with 0,50 and $75 \mu \mathrm{M}$ of ANK-199 for $24 \mathrm{~h}$. Cells were then fixed on ice with $4 \%$ paraformaldehyde, and the slides were mounted and analyzed by a fluorescence microscope. After treatments, cells were stained with 4',6-diamidino-2-phenylindole (DAPI, Molecular Probes/Life Technologies) and photographed using a fluorescence microscope $(46,47,49)$.

Western blot analysis. CAR cells $\left(1 \times 10^{7}\right.$ cells/75-T flask) were treated with ANK-199 (50 and $75 \mu \mathrm{M})$ for $48 \mathrm{~h}$. At the end of incubation, the total proteins were prepared, and the protein concentration was measured by using a BCA assay kit (Pierce Chemical, Rockford, IL, USA). Equal amounts of cell lysates were run on $10 \%$ SDS-polyacrylamide gel electrophoresis and further employed by immunoblotting as described by Lin et al (46).

Real-time PCR analysis. CAR cells at a density of 5x10 6 in T75 flasks were incubated with or without 50 and $75 \mu \mathrm{M}$ of ANK-199 for $24 \mathrm{~h}$. Cells were collected, and total RNA was extracted by the Qiagen RNeasy mini kit (Qiagen Inc., Valencia, CA, USA). Each RNA sample was individually reverse-transcribed using the High Capacity cDNA Reverse Transcription kits (Applied Biosystems, Foster City, CA, USA). Quantitative PCR was assessed for amplifications with 2X SYBR-Green PCR Master mix (Applied Biosystems), as well as forward and reverse primers for Atg7, Atg12, beclin 1 and LC3-II gene. (Human ATG7-F-CAGCAGTGACGATCGGATGA; human ATG7-R-GACGGGAAGGACATTATCAAACC; human ATG12-F-TGTGGCCTCAGAACAGTTGTTTA; human ATG12-R-CGCCTGAGACTTGCAGTAATGT; human BECN1-F-GGATGGTGTCTCTCGCAGATTC; human BECN1-R-GGTGCCGCCATCAGATG; human LC3-II-F-CCG ACCGCTGTAAGGAGGTA; human LC3-II-R-AGGACGG GCAGCTGCTT) Applied Biosystems 7300 Real-Time PCR System was run in triplicate, and each value was expressed in the comparative threshold cycles (CT) method for the housekeeping gene GAPDH.

cDNA microarray analysis. CAR cells $\left(5 \times 10^{6}\right.$ per T75 flask) were incubated with or without $75 \mu \mathrm{M}$ of ANK-199 for $24 \mathrm{~h}$. Cells were scraped and collected by centrifugation. The total RNA was subsequently isolated as stated above, and the purity was assessed at 260 and $280 \mathrm{~nm}$ using a Nanodrop (ND-1000; Labtech International). Each sample (300 ng) was amplified and labeled using the GeneChip WT Sense Target Labeling and Control Reagents (900652) for Expression Analysis. Hybridization was performed against the Affymetrix GeneChip Human Gene 1.0 ST array. The arrays were hybridized for $17 \mathrm{~h}$ at $45^{\circ} \mathrm{C}$ and $60 \mathrm{rpm}$. Arrays were subsequently washed (Affymetrix Fluidics Station 450), stained with streptavidinphycoerythrin (GeneChip Hybridization, Wash, and Stain Kit, 900720), and scanned on an Affymetrix GeneChip Scanner 3000. Resulting data were analyzed by using Expression Console software (Affymetrix) with default RMA parameters. Genes regulated by ANK-199 were determined with a 1.5-fold change. For detection of significantly over-represented GO biological processes, the DAVID functional annotation clustering tool (http://david.abcc.ncifcrf.gov) was used (DAVID Bioinformatics Resources 6.7). Enrichment was determined at DAVID calculated Benjamini value $<0.05$. Significance of overexpression of individual genes was determined (50).

Statistical analysis. All the statistical results were expressed as the mean \pm SEM of triplicate samples. Statistical analyses of data were done using one-way ANOVA followed by Student's $\mathrm{t}$-test, and ${ }^{*} \mathrm{p}<0.05$ and ${ }^{* * *} \mathrm{p}<0.001$ were considered significant.

\section{Results}

ANK-199 exhibits cytotoxicity and inhibits viable CAR cells. CAR cells were treated with different concentrations of ANK-199 for 24, 48 and $72 \mathrm{~h}$. ANK-199 concentration- and time-dependently decreased cell viability of CAR cells (Fig. 2A). The half maximal inhibitory concentration $\left(\mathrm{IC}_{50}\right)$ for a 24, 48 and 72-h treatment of ANK-199 in CAR cells were $106.21 \pm 3.21,73.25 \pm 4.20$ and $32.58 \pm 2.39 \mu \mathrm{M}$, respectively. To investigate whether the cell death was mediated through apoptosis by ANK-199, cells were treated with 50 and $75 \mu \mathrm{M}$ ANK-199 for $48 \mathrm{~h}$. The appearance of DNA fragmentation was not observed (data not shown), suggesting that ANK-199 was unable to induce apoptosis in CAR cells. As shown in Fig. 2B, ANK-199 was able to induce the formation of autophagic vacuoles in CAR cells in a time-dependent manner in the presence of $50 \mu \mathrm{M}$ ANK-199 for 24, 48 and $72 \mathrm{~h}$. This result implies that autophagic cell death plays a pivotal role in ANK-199-induced cell death. However, no viability impact and morphological trait change was observed in ANK-199-treated HGF and OK cells, suggesting that ANK-199 has an extremely low toxicity in normal oral cell lines. In accordance with this observation, the $\mathrm{IC}_{50}$ value of $\mathrm{HGF}$ and $\mathrm{OK}$ cells is greater than $100 \mu \mathrm{M}$ (Fig. 3A and B). In short, ANK-199-induced cell death of CAR cells is mediated through autophagic death, rather than apoptosis.

ANK-199 induces autophagic cell death in CAR cells. To further confirm the formation of autophagosome vesicles in ANK-199-treated CAR cells, the autophagic cell death caused by ANK-199 was monitored by using MDC staining, a popular fluorescent marker that preferentially accumulates in autophagic vacuoles $(46,48)$. After cells were treated with 50 and $75 \mu \mathrm{M}$ of ANK-199 for $48 \mathrm{~h}$, autophagic vacuoles were easily observed under fluorescence microscopy (Fig. 4A). The intensity of MDC staining was directly proportional to the concentration of ANK-199. The ANK-199-triggered autophagic cell death was also examined by using AO staining. In Fig. 4B, AO staining of ANK-199-treated CAR cells clearly showed the presence of AVOs within the cytoplasm compared to control. Microtubuleassociated protein 1 light-chain 3 (LC3) is an autophagic membrane marker for the detection of early autophagosome formation $(46,49)$. The LC3 distribution in ANK-199-treated CAR cells was also investigated. A more punctate pattern of LC3B-GFP was observed in ANK-199 treated cells (Fig. 4C). The occurrence of DNA condensation was also investigated in the presence of 50 and $75 \mu \mathrm{M}$ ANK-199 for $24 \mathrm{~h}$. No significant change was observed in ANK-199-treated CAR cells under microscope, which means that ANK-199-induced cell death triggered by apoptosis is quite unlikely (Fig. 4D). Again, all of the above results support that ANK-199-induced cell death in CAR cells is mediated through the induction of autophagic death instead of apoptosis. 


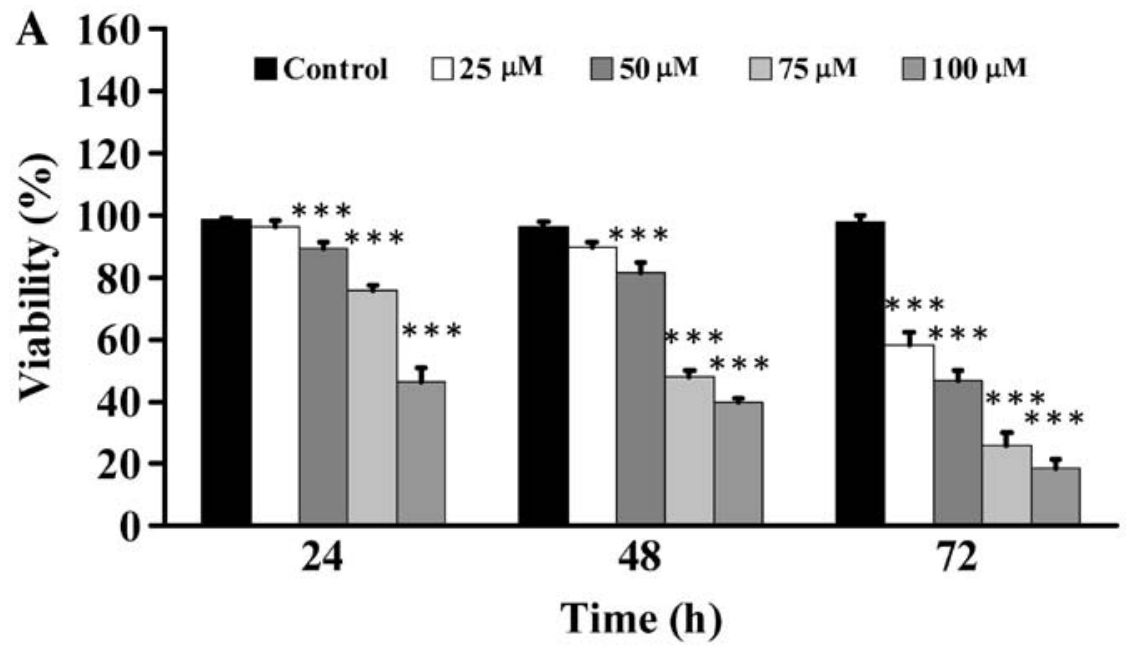

B
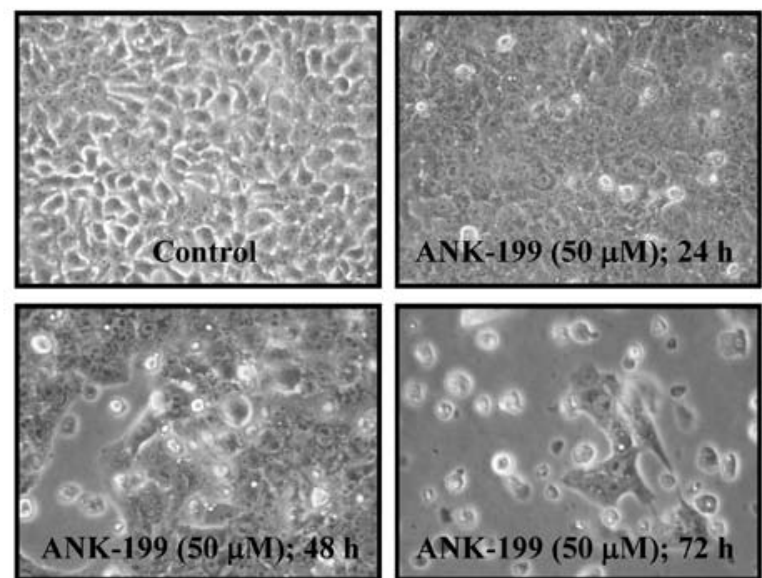

Figure 2. Effect of ANK-199 on CAR cell viability and morphological examination. CAR cells were treated with or without various concentrations of ANK-199 for 24,28 and $72 \mathrm{~h}$. (A) Cell viability was measured by MTT assay. Data are presented as the mean $\pm \operatorname{SEM}(\mathrm{n}=3){ }^{* * * *} \mathrm{p}<0.001$ vs. vehicle control. (B) Cells were photographed with a phase-contrast microscope.

A

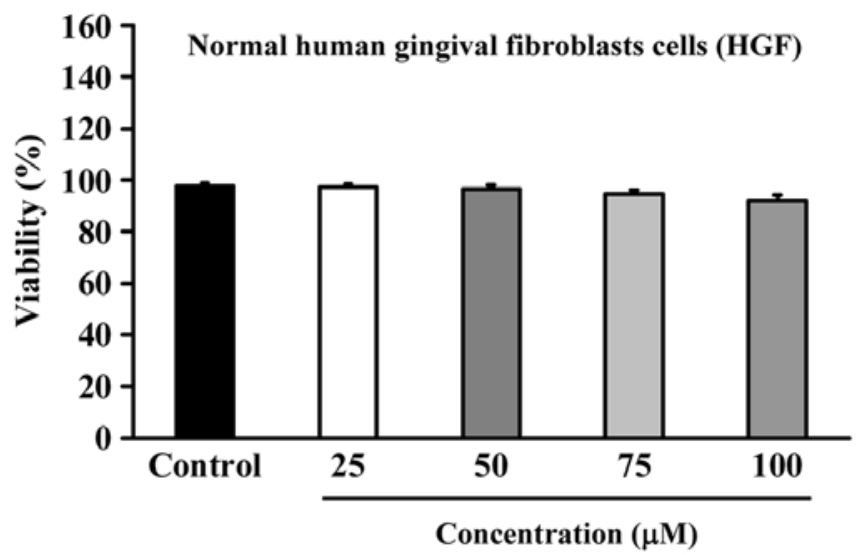

B

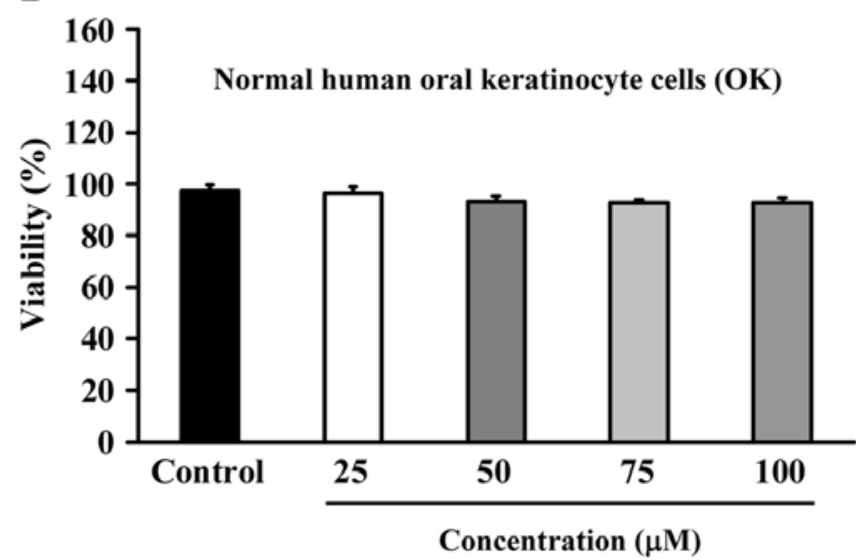

Figure 3. Effect of ANK-199 on normal oral cells. (A) Normal human gingival fibroblasts cells (HGF) and (B) normal human oral keratinocyte cells (OK) cells after exposure to various concentrations of ANK-199 for $72 \mathrm{~h}$ were determined by MTT assay. The data shown represent the mean \pm SEM ( $\mathrm{n}=3$ ).

ANK-199 upregulates the autophagy-associated protein levels in CAR cells. The protein level of autophagy marker proteins, like Atg complex (Atg5, Atg7, Atg12, Atg14 and Atg16L1), beclin 1, PI3K class III, rubicon and LC3, was also 
$\mathbf{A}$
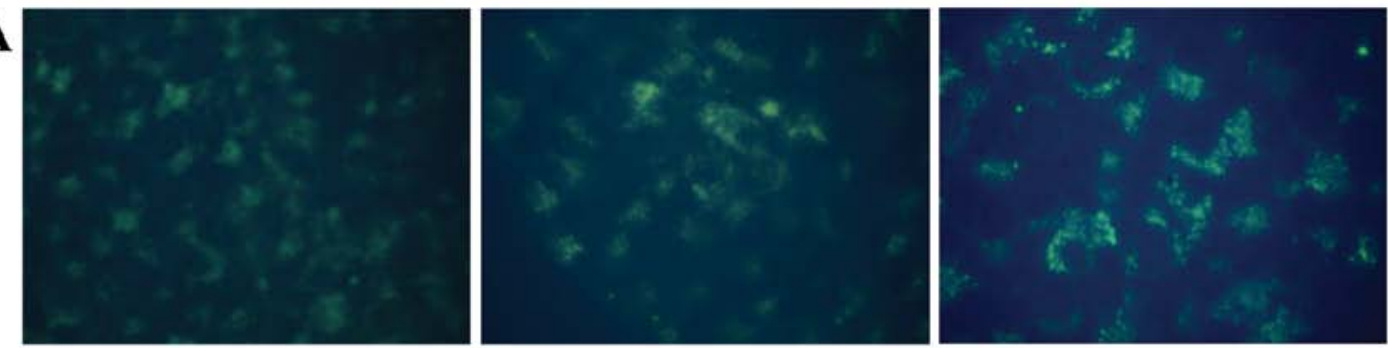

Control

ANK-199 $(50 \mu \mathrm{M}) ; 48$ h

ANK-199 (75 $\mu \mathrm{M}) ; 48 \mathrm{~h}$

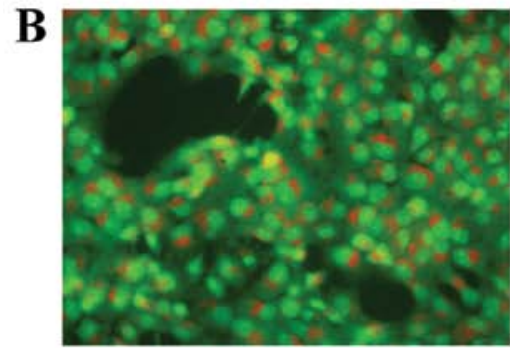

Control

C

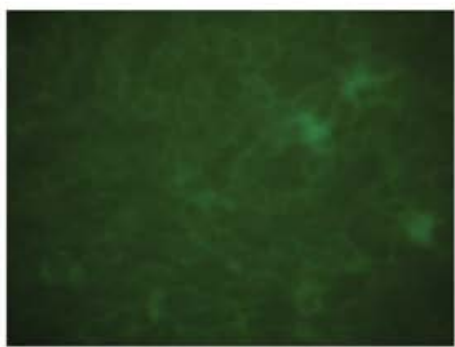

Control

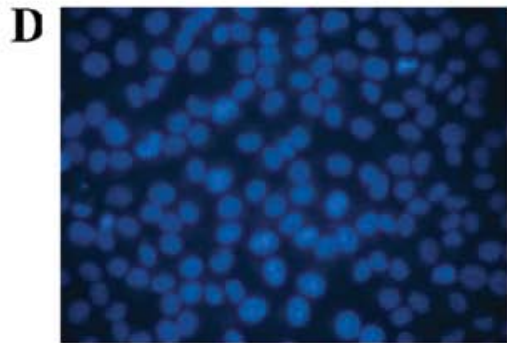

Control

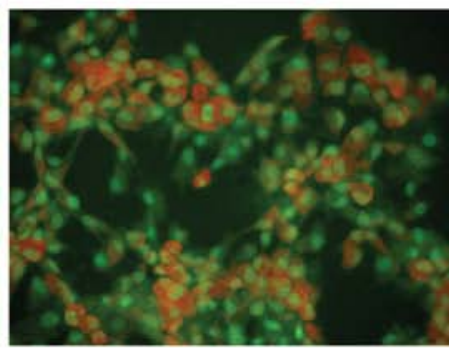

ANK-199 $(50 \mu \mathrm{M}) ; 48 \mathrm{~h}$

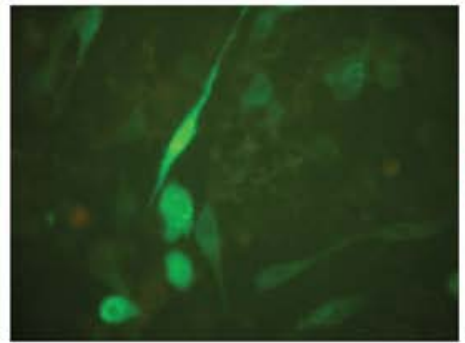

ANK-199 (50 $\mu \mathrm{M}) ; 48$ h

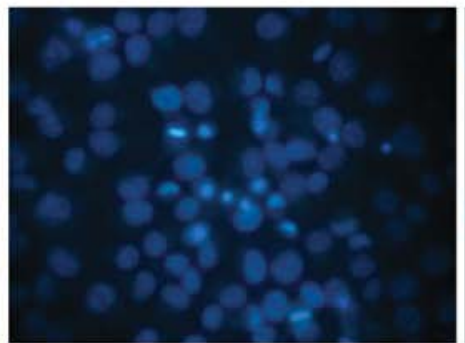

ANK-199 (50 $\mu \mathrm{M}) ; 48 \mathrm{~h}$

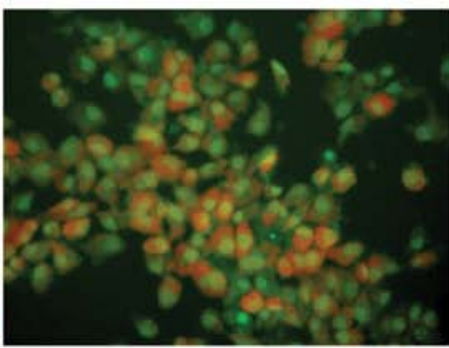

ANK-199 $(75 \mu \mathrm{M}) ; 48 \mathrm{~h}$

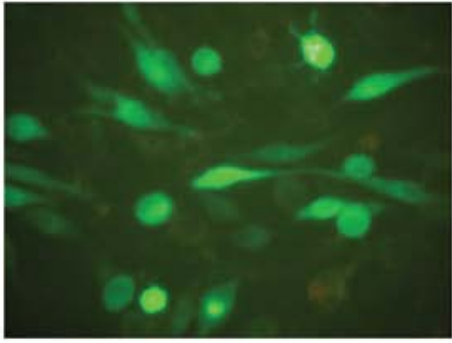

ANK-199 $(75 \mu \mathrm{M}) ; 48$ h

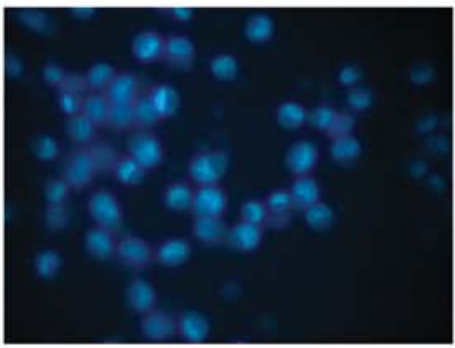

ANK-199 (75 $\mu \mathrm{M}) ; 48 \mathrm{~h}$

Figure 4. Effect of ANK-199 on autophagic death in CAR cells. Cells in the presence and absence of ANK-199 challenge for 24 h were harvested. (A) The autophagolysosome marker was probed by MDC. (B) AO staining was used to detect AVO. (C) LC3B expression was determined by Premo Autophagy Sensor kit. (D) DNA condensation (an apoptotic characteristic) was tested utilizing DAPI staining.

investigated in ANK-199-treated CAR cells. As shown in Fig. 5, ANK-199 at 50 and $75 \mu \mathrm{M}$ increased the protein levels of Atg5, Atg7, Atg12, Atg14 and Atg16L1, beclin 1, PI3K class III and LC3, but decreased the protein level of rubicon in CAR cells. Our results imply that ANK-199 induced autophagic cell death in CAR cells through interfering with the kinase class III/beclin 1/Atg-associated signal pathway.

ANK-199 stimulates the autophagy-associated mRNA levels in CAR cells. The mRNA level of autophagy-associated gene was also investigated in ANK-199-treated CAR cells. As shown in Fig. 6, ANK-199 is able to enhance the expression level of Atg7 gene (Fig. 6A), Atg12 gene (Fig. 6B), beclin 1 gene (Fig. 6C) and LC3-II gene (Fig. 6D) in CAR cells.

Protection effect of 3-MA against autophagy in ANK-199treated CAR cells. 3-MA, an inhibitor of PI3K kinase class III, has been shown to potently inhibit autophagy-dependent protein degradation and suppress the formation of autophagosomes. CAR cells were pretreated with 3-MA and then exposed to 50 


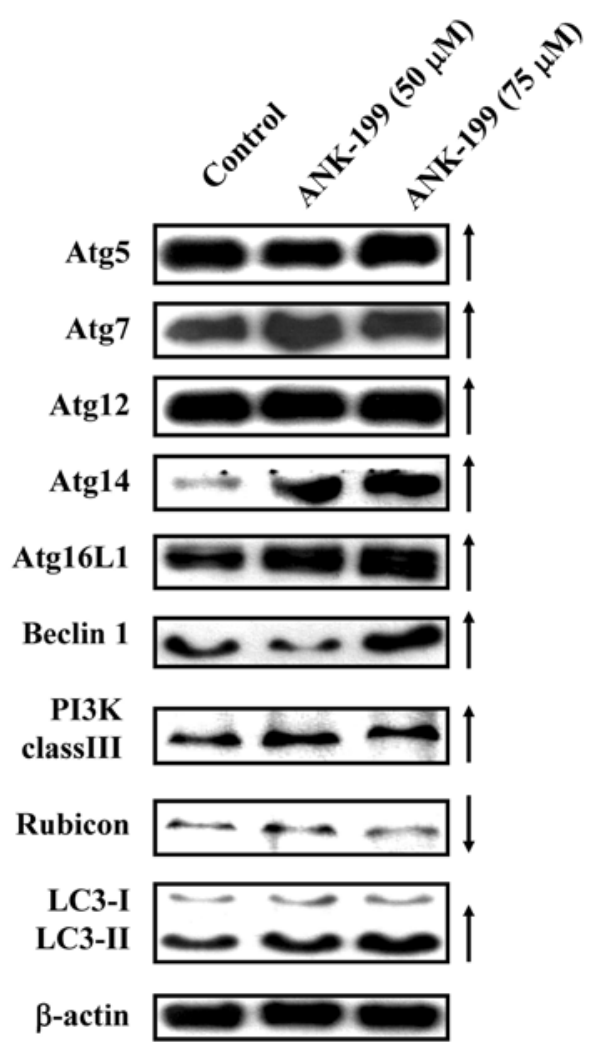

Figure 5. Effect of ANK-199 on autophagy-regulated signaling in CAR cells. Immunoblot analysis of the molecules of vehicle control or ANK-199 treatment at 50 and $75 \mu \mathrm{M}$ of CAR cells for $48 \mathrm{~h}$ showed autophagy-modulated signal molecules (Atg5, Atg7, Atg12, Atg14, Atg16L1, beclin 1, PI3K class III, rubicon, $\mathrm{LC} 3$ ) as described in Materials and methods. The anti- $\beta$-actin $\mathrm{mAb}$ was used as an internal control for loading. or $75 \mu \mathrm{M}$ of ANK-199. The formation of autophagic vacuoles and cell viability were then monitored under phase contrast microscopy. Our results showed that 3-MA can inhibit the formation of autophagic vacuoles (Fig. 7A) and enhance the viability of ANK-199-treated CAR cells (Fig. 7B), suggesting that ANK-199-induced autophagy in CAR cells is mediated through interference with the PI3K kinase class III.

Microarray analysis. The cDNA microarray experiments were carried out to examine the gene expression in ANK-199-treated CAR cells. The transcripts of 26 genes were upregulated, while these of 96 genes were downregulated in ANK-199-treated CAR cells (Table I). The important biological processes and Gene to Go Molecular Function test regulated by ANK-199 are listed in Table II and Table III. The formation of autophagosomes and autophagolysosome was observed during the course of ANK-199 induced autophagic cell death. In a good agreement with above results, membrane formation or reorganization is closely associated with following biological processes: cellular component biogenesis, actin cytoskeleton organization, regulation of actin filament-based process, regulation of cytoskeleton organization, regulation of actin polymerization or depolymerization, regulation of actin filament length.

\section{Discussion}

Apoptosis, autophagy and necrosis are three major routes that lead to cell death (51). Both apoptosis and autophagy belong to the form of cell programmed death, but necrosis does not (51-54). Autophagic death can promote cell survival or cell death when cells experience stress, such as damage, nutrient
A

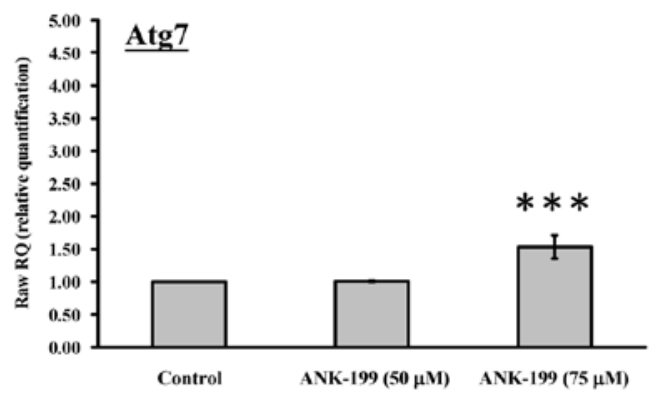

C

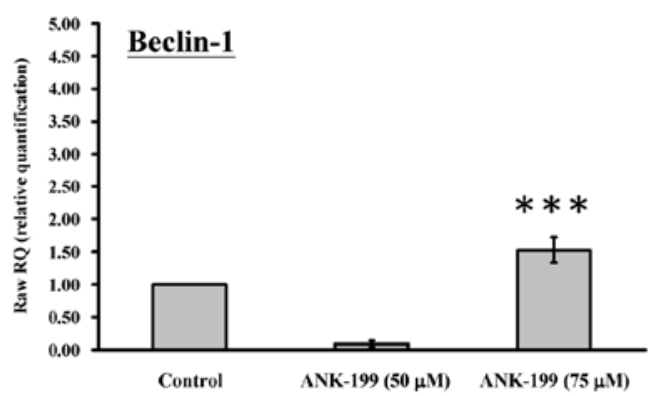

B

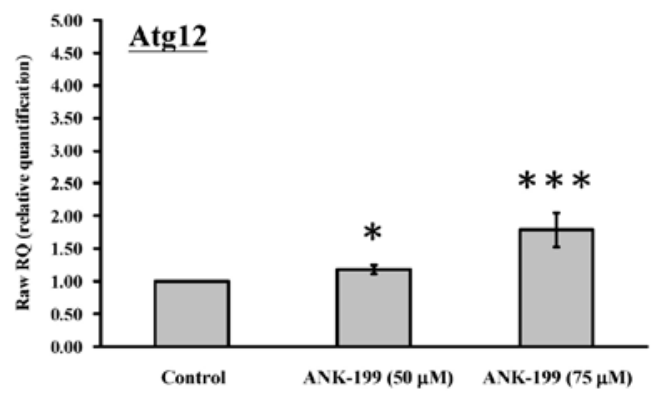

D

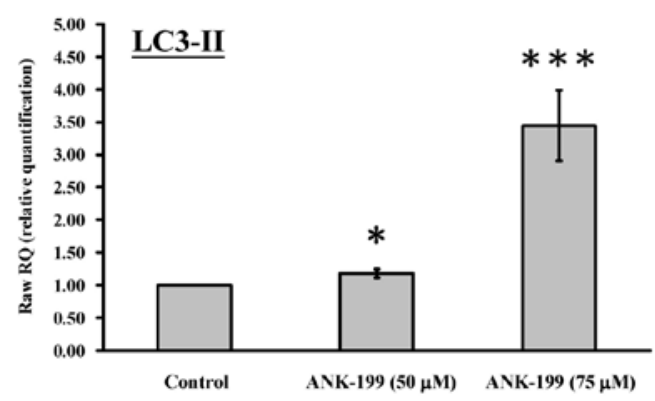

Figure 6. Effect of ANK-199 on autophagy-related gene expression in CAR cells. Total RNA was extracted from CAR cells after ANK-199 treatment, and realtime PCR was performed for different specific primers, including (A) Atg7, (B) Atg12, (C) beclin-1 and (D) LC3-II gene levels. GAPDH is as an internal control gene. The results are given as mean $\pm \operatorname{SEM}(\mathrm{n}=3),{ }^{*} \mathrm{p}<0.05$ and $^{* * *} \mathrm{p}<0.001$ vs. vehicle control. 
A

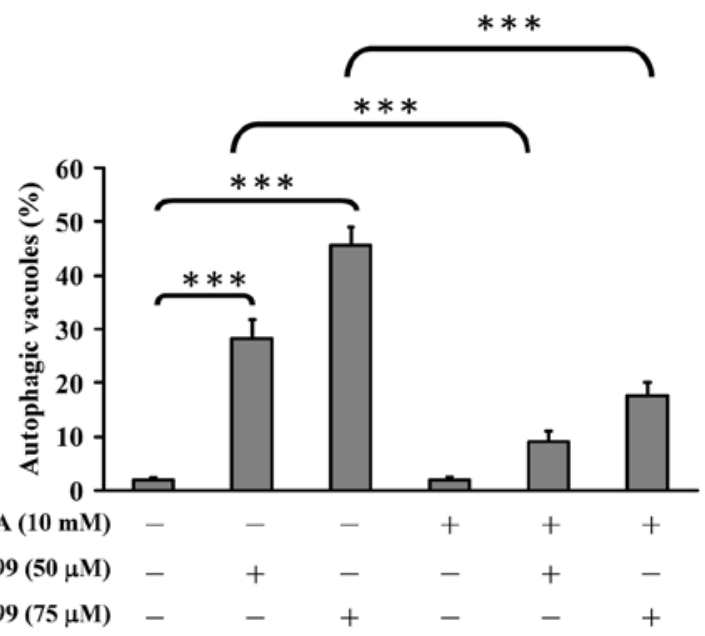

B

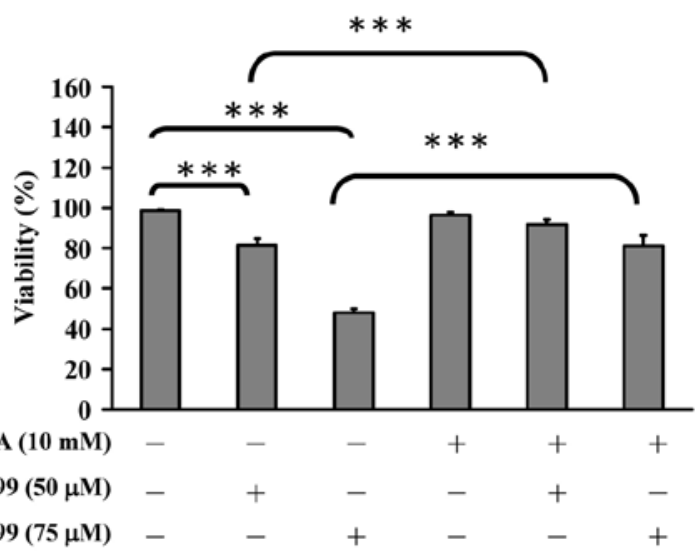

Figure 7. Effect of 3-MA on autophagic death in ANK-199-treated CAR cells. Cells were pretreated with $10 \mathrm{mM} 3$-MA and then exposed to 50 or $75 \mu \mathrm{M}$ of ANK-199 for $48 \mathrm{~h}$. (A) The autophagic vacuole formation was assessed using MDC staining, and (B) MTT assay was applied to estimate cell viability. All values are expressed as mean \pm SEM $(\mathrm{n}=3) .{ }^{* * * *} \mathrm{p}<0.001$ vs. vehicle control or ANK-199 treatment groups.

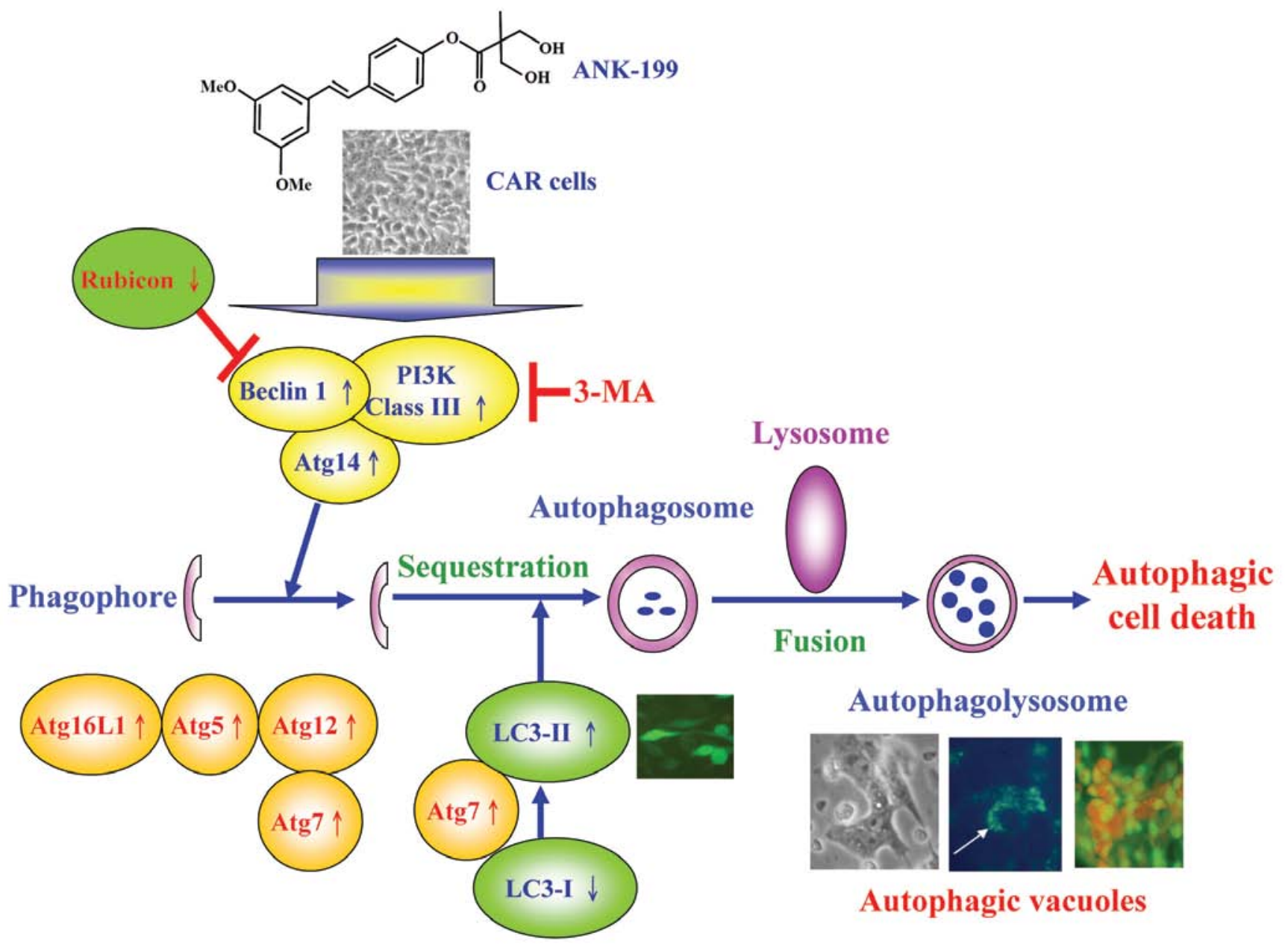

Figure 8. Proposed schematic molecular signaling for ANK-199-triggered autophagy in cisplatin-resistant human oral cancer CAR cells.

starvation, aging and pathogen infection (55-57). Indeed, induction of autophagic death for cancer cells is thought to be one of the best strategies in chemotherapy (58-60). Not only many autophagy-related proteins (Atgs) are involved in this process, but also a specific morphological and biochemical modification can be observed $(56,60,61)$. Autophagy is first 
Table I. The genes with more than 1.5-fold changes in mRNA levels in CAR cells after ANK-199 (50 $\mu \mathrm{M})$ 24-h treatment identified by DNA microarray.

\begin{tabular}{|c|c|c|}
\hline Accession & Gene & $\mathrm{FC}$ \\
\hline XR_042379 & LOC401875: hypothetical LOC401875 & 7.34 \\
\hline NM_198581 & ZC3H6: zinc finger CCCH-type containing 6 & 5.68 \\
\hline NM_004755 & RPS6KA5: ribosomal protein S6 kinase, $90 \mathrm{kDa}$, polypeptide 5 & 3.27 \\
\hline NM_006472 & TXNIP: thioredoxin interacting protein & 3.00 \\
\hline NM_001506 & GPR32: G protein-coupled receptor 32 & 2.15 \\
\hline NM_018387 & STRBP: spermatid perinuclear RNA binding protein & 2.04 \\
\hline ВC007928 & C21orf119: chromosome 21 open reading frame 119 & 1.93 \\
\hline ВC108718 & LOC389765: similar to KIF27C & 1.88 \\
\hline NM_153335 & LYK5: protein kinase LYK5 & 1.86 \\
\hline ENST00000021776 & CCT8L1: chaperonin containing TCP1, subunit 8 (theta)-like 1 & 1.81 \\
\hline NM_018434 & RNF130: ring finger protein 130 & 1.75 \\
\hline NM_181684 & KRTAP12-2: keratin associated protein $12-2$ & 1.72 \\
\hline NM_201266 & NRP2: neuropilin 2 & 1.71 \\
\hline NM_181351 & NCAM1: neural cell adhesion molecule 1 & 1.63 \\
\hline NM_004064 & CDKN1B: cyclin-dependent kinase inhibitor 1B (p27, Kip1) & 1.63 \\
\hline NM_007051 & FAF1: Fas (TNFRSF6) associated factor 1 & 1.62 \\
\hline NM_001039752 & SLC22A10: solute carrier family 22, member 10 & 1.62 \\
\hline NM_198993 & STAC2: SH3 and cysteine rich domain 2 & 1.62 \\
\hline NM_018257 & PCMTD2: protein-L-isoaspartate (D-aspartate) O-methyltransferase domain containing 2 & 1.62 \\
\hline NM_000901 & NR3C2: nuclear receptor subfamily 3 , group $C$, member 2 & 1.62 \\
\hline ВС093665 & FAM92B: family with sequence similarity 92 , member B & 1.56 \\
\hline NM_016609 & SLC22A17: solute carrier family 22, member 17 & 1.55 \\
\hline NM_181605 & KRTAP6-3: keratin associated protein 6-3 & 1.55 \\
\hline XM_938903 & LOC649839: similar to large subunit ribosomal protein L36a & 1.53 \\
\hline ВC021739 & LOC554201: hypothetical LOC554201 & 1.53 \\
\hline ENST00000329244 & LOC100132169: similar to hCG1742852 & 1.50 \\
\hline NM_021109 & TMSB4X: thymosin beta $4, \mathrm{X}$-linked & -1.50 \\
\hline NM_019896 & POLE4: polymerase (DNA-directed), epsilon 4 (p12 subunit) & -1.51 \\
\hline NM_015475 & FAM98A: family with sequence similarity 98 , member A & -1.51 \\
\hline NM_006136 & CAPZA2: capping protein (actin filament) muscle Z-line, alpha 2 & -1.51 \\
\hline NM_001128619 & LUZP6: leucine zipper protein 6 & -1.51 \\
\hline NM_014248 & $\mathrm{RBX} 1$ : ring-box 1 & -1.52 \\
\hline NM_024755 & SLTM: SAFB-like, transcription modulator & -1.53 \\
\hline NM_003168 & SUPT4H1: suppressor of Ty 4 homolog 1 (S. cerevisiae) & -1.53 \\
\hline NM_017892 & PRPF40A: PRP40 pre-mRNA processing factor 40 homolog A (S. cerevisiae) & -1.53 \\
\hline NM_004776 & B4GALT5: UDP-Gal:betaGlcNAc beta 1,4-galactosyltransferase, polypeptide 5 & -1.53 \\
\hline NM_002090 & CXCL3: chemokine (C-X-C motif) ligand 3 & -1.53 \\
\hline NM_001005333 & MAGED1: melanoma antigen family D, 1 & -1.53 \\
\hline NM_000937 & POLR2A: polymerase (RNA) II (DNA directed) polypeptide A, $220 \mathrm{kDa}$ & -1.54 \\
\hline NM_001349 & DARS: aspartyl-tRNA synthetase & -1.55 \\
\hline NM_003348 & UBE2N: ubiquitin-conjugating enzyme E2N (UBC13 homolog, yeast) & -1.56 \\
\hline NM_001614 & ACTG1: actin, gamma 1 & -1.56 \\
\hline NM_053024 & PFN2: profilin 2 & -1.56 \\
\hline
\end{tabular}


Table I. Continued.

\begin{tabular}{|c|c|c|}
\hline Accession & Gene & FC \\
\hline NM_003010 & MAP2K4: mitogen-activated protein kinase kinase 4 & -1.57 \\
\hline NM_001099771 & A26C1B: ANKRD26-like family C, member 1B & -1.57 \\
\hline NM_006000 & TUBA4A: tubulin, alpha 4a & -1.58 \\
\hline NM_133494 & NEK7: NIMA (never in mitosis gene a)-related kinase 7 & -1.59 \\
\hline NM_173647 & RNF149: ring finger protein 149 & -1.59 \\
\hline NM_182917 & EIF4G1: eukaryotic translation initiation factor 4 gamma, 1 & -1.59 \\
\hline NM_002599 & PDE2A: phosphodiesterase 2A, cGMP-stimulated & -1.62 \\
\hline NM_005066 & SFPQ: splicing factor proline/glutamine-rich (polypyrimidine tract binding protein associated) & -1.64 \\
\hline NM_001039479 & KIAA0317: KIAA0317 & -1.64 \\
\hline NM_001127649 & PEX26: peroxisomal biogenesis factor 26 & -1.64 \\
\hline NM_015153 & PHF3: PHD finger protein 3 & -1.64 \\
\hline NM_007189 & ABCF2: ATP-binding cassette, sub-family F (GCN20), member 2 & -1.64 \\
\hline NM_007126 & VCP: valosin-containing protein & -1.64 \\
\hline NM_012234 & RYBP: RING1 and YY1 binding protein & -1.65 \\
\hline NR_004845 & LOC644936: cytoplasmic beta-actin pseudogene & -1.65 \\
\hline NM_014795 & ZEB2: zinc finger E-box binding homeobox 2 & -1.66 \\
\hline NM_005998 & CCT3: chaperonin containing TCP1, subunit 3 (gamma) & -1.67 \\
\hline NM_001099692 & EIF5AL1: eukaryotic translation initiation factor 5A-like 1 & -1.67 \\
\hline NM_138689 & PPP1R14B: protein phosphatase 1, regulatory (inhibitor) subunit 14B & -1.67 \\
\hline NM_015665 & AAAS: achalasia, adrenocortical insufficiency, alacrimia (Allgrove, triple-A) & -1.67 \\
\hline NM_001099692 & EIF5AL1: eukaryotic translation initiation factor 5A-like 1 & -1.68 \\
\hline NM_001099692 & EIF5AL1: eukaryotic translation initiation factor 5A-like 1 & -1.68 \\
\hline NM_002154 & HSPA4: heat shock $70 \mathrm{kDa}$ protein 4 & -1.68 \\
\hline NM_013451 & FER1L3: fer-1-like 3, myoferlin (C. elegans) & -1.70 \\
\hline NM_000303 & PMM2: phosphomannomutase 2 & -1.71 \\
\hline NM_002795 & PSMB3: proteasome (prosome, macropain) subunit, beta type, 3 & -1.71 \\
\hline NM_001363 & DKC1: dyskeratosis congenita 1 , dyskerin & -1.71 \\
\hline NM_001102 & ACTN1: actinin, alpha 1 & -1.73 \\
\hline NM_004299 & ABCB7: ATP-binding cassette, sub-family B (MDR/TAP), member 7 & -1.73 \\
\hline NM_005857 & ZMPSTE24: zinc metallopeptidase (STE24 homolog, S. cerevisiae) & -1.74 \\
\hline NM_152265 & BTF3L4: basic transcription factor 3-like 4 & -1.74 \\
\hline NM_020409 & MRPL47: mitochondrial ribosomal protein L47 & -1.74 \\
\hline NM_006148 & LASP1: LIM and SH3 protein 1 & -1.76 \\
\hline ВС065192 & C2orf12: chromosome 2 open reading frame 12 & -1.76 \\
\hline NM_001414 & EIF2B1: eukaryotic translation initiation factor 2B, subunit 1 alpha, $26 \mathrm{kDa}$ & -1.78 \\
\hline NM_003222 & TFAP2C: transcription factor AP-2 gamma (activating enhancer binding protein 2 gamma) & -1.78 \\
\hline NM_007350 & PHLDA1: pleckstrin homology-like domain, family A, member 1 & -1.79 \\
\hline ENST00000242577 & DYNLL1: dynein, light chain, LC8-type 1 & -1.79 \\
\hline NM_032830 & CIRH1A: cirrhosis, autosomal recessive 1A (cirhin) & -1.79 \\
\hline NM_152265 & BTF3L4: basic transcription factor 3-like 4 & -1.80 \\
\hline NM_176816 & CCDC125: coiled-coil domain containing 125 & -1.80 \\
\hline NM_001039690 & CTF8: chromosome transmission fidelity factor 8 homolog (S. cerevisiae $)$ & -1.83 \\
\hline NM_001127257 & SLC39A10: solute carrier family 39 (zinc transporter), member 10 & -1.84 \\
\hline XM_001716411 & LOC128322: hypothetical LOC128322 & -1.86 \\
\hline
\end{tabular}


Table I. Continued.

\begin{tabular}{|c|c|c|}
\hline Accession & Gene & FC \\
\hline NM_002370 & MAGOH: mago-nashi homolog, proliferation-associated (Drosophila) & -1.90 \\
\hline NM_138578 & BCL2L1: BCL2-like 1 & -1.91 \\
\hline NM_003580 & NSMAF: neutral sphingomyelinase (N-SMase) activation associated factor & -1.92 \\
\hline NM_015922 & NSDHL: NAD(P) dependent steroid dehydrogenase-like & -1.92 \\
\hline NM_001797 & CDH11: cadherin 11, type 2, OB-cadherin (osteoblast) & -1.93 \\
\hline NM_021242 & MID1IP1: MID1 interacting protein 1 [gastrulation specific G12 homolog (zebrafish)] & -1.93 \\
\hline NM_005968 & HNRNPM: heterogeneous nuclear ribonucleoprotein M & -1.95 \\
\hline NM_012338 & TSPAN12: tetraspanin 12 & -1.97 \\
\hline NM_014953 & DIS3: DIS3 mitotic control homolog (S. cerevisiae) & -2.02 \\
\hline NM_003130 & SRI: sorcin & -2.11 \\
\hline NM_018993 & RIN2: Ras and Rab interactor 2 & -2.12 \\
\hline NM_004093 & EFNB2: ephrin-B2 & -2.13 \\
\hline NM_032256 & TMEM117: transmembrane protein 117 & -2.14 \\
\hline NM_005415 & SLC20A1: solute carrier family 20 (phosphate transporter), member 1 & -2.15 \\
\hline NM_017872 & THG1L: tRNA-histidine guanylyltransferase 1-like (S. cerevisiae) & -2.20 \\
\hline NM_014624 & S100A6: S100 calcium binding protein A6 & -2.24 \\
\hline NM_153618 & $\begin{array}{l}\text { SEMA6D: sema domain, transmembrane domain (TM), and cytoplasmic domain, } \\
\text { (semaphorin) 6D }\end{array}$ & -2.27 \\
\hline NM_014604 & TAX1BP3: Tax1 (human T-cell leukemia virus type I) binding protein 3 & -2.27 \\
\hline NM_033505 & SELI: selenoprotein I & -2.30 \\
\hline NM_003666 & BLZF1: basic leucine zipper nuclear factor 1 & -2.35 \\
\hline NM_002714 & PPP1R10: protein phosphatase 1, regulatory (inhibitor) subunit 10 & -2.50 \\
\hline NM_002714 & PPP1R10: protein phosphatase 1, regulatory (inhibitor) subunit 10 & -2.50 \\
\hline NM_002714 & PPP1R10: protein phosphatase 1, regulatory (inhibitor) subunit 10 & -2.50 \\
\hline NR_003003 & SCARNA17: small Cajal body-specific RNA 17 & -2.51 \\
\hline NR_002738 & SNORD57: small nucleolar RNA, C/D box 57 & -2.57 \\
\hline NM_006080 & $\begin{array}{l}\text { SEMA3A: sema domain, immunoglobulin domain (Ig), short basic domain, secreted, } \\
\text { (semaphorin) } 3 \mathrm{~A}\end{array}$ & -2.57 \\
\hline NM_009587 & LGALS9: lectin, galactoside-binding, soluble, 9 & -2.65 \\
\hline NM_003234 & TFRC: transferrin receptor (p90, CD71) & -2.85 \\
\hline NM_138966 & NETO1: neuropilin (NRP) and tolloid (TLL)-like 1 & -2.97 \\
\hline NM_001098272 & HMGCS1: 3-hydroxy-3-methylglutaryl-Coenzyme A synthase 1 (soluble) & -2.97 \\
\hline NM_006350 & FST: follistatin & -4.21 \\
\hline NM_024090 & $\begin{array}{l}\text { ELOVL6: ELOVL family member 6, elongation of long chain fatty acids } \\
\text { (FEN1/Elo2, SUR4/Elo3-like, yeast) }\end{array}$ & -4.46 \\
\hline NM_005328 & HAS2: hyaluronan synthase 2 & -5.00 \\
\hline NM_001753 & CAV1: caveolin 1, caveolae protein, $22 \mathrm{kDa}$ & -5.04 \\
\hline NM_033439 & IL33: interleukin 33 & -5.96 \\
\hline
\end{tabular}

FC, fold change.

triggered by membrane nucleation, which is mediated by phosphatidylinositol 3-kinase (PI3K) class III, beclin 1 (the mammalian ortholog of yeast ATG6), rubicon and
Atg14 (62-64). The cytoplasm and phagophore of various organelles are then sequestered by a membrane to form an autophagosomes. Atg16L1-Atg12-Atg7-Atg5 complex and 
Table II. Gene to GO Biological Process test for over-representation (ANK-199 to control).

\begin{tabular}{lccc}
\hline Term & Count & $\%$ & p-value \\
\hline GO:0044087 - regulation of cellular component biogenesis & 9 & 6.382979 & $8.59 \mathrm{E}-06$ \\
GO:0030036 - actin cytoskeleton organization & 10 & 7.092199 & $3.75 \mathrm{E}-05$ \\
GO:0032956 - regulation of actin cytoskeleton organization & 7 & 4.964539 & $4.43 \mathrm{E}-05$ \\
GO:0043254 - regulation of protein complex assembly & 7 & 4.964539 & $4.72 \mathrm{E}-05$ \\
GO:0032970 - regulation of actin filament-based process & 7 & 4.964539 & $5.34 \mathrm{E}-05$ \\
GO:0051493 - regulation of cytoskeleton organization & 8 & 5.673759 & $5.75 \mathrm{E}-05$ \\
GO:0030029 - actin filament-based process & 10 & 7.092199 & $6.17 \mathrm{E}-05$ \\
GO:0007010 - cytoskeleton organization & 13 & 9.219858 & $7.13 \mathrm{E}-05$ \\
GO:0008064 - regulation of actin polymerization or depolymerization & 6 & 4.255319 & $7.77 \mathrm{E}-05$ \\
GO:0030832 - regulation of actin filament length & 6 & 4.255319 & $9.07 \mathrm{E}-05$ \\
\hline
\end{tabular}

Table III. Gene to GO Molecular Function test for over-representation (ANK-199 to control).

\begin{tabular}{lccc}
\hline Term & Count & $\%$ & p-value \\
\hline GO:0003723 - RNA binding & 21 & 14.89362 & $1.54 \mathrm{E}-07$ \\
GO:0000166 - nucleotide binding & 33 & 23.40426 & $6.28 \mathrm{E}-05$ \\
GO:0008092 - cytoskeletal protein binding & 11 & 7.801418 & 0.00346 \\
GO:0032553 - ribonucleotide binding & 24 & 17.02128 & 0.005183 \\
GO:0032555 - purine ribonucleotide binding & 24 & 17.02128 & 0.005183 \\
GO:0017076 - purine nucleotide binding & 24 & 17.02128 & 0.008794 \\
GO:0003779 - actin binding & 8 & 5.673759 & 0.009366 \\
GO:0019900 - kinase binding & 6 & 4.255319 & 0.009636 \\
GO:0047485 - protein N-terminus binding & 4 & 2.836879 & 0.016454 \\
GO:0003924 - GTPase activity & 6 & 4.255319 & 0.018492 \\
\hline
\end{tabular}

microtubule-associated protein 1 light chain 3 type II (LC3-II) (membrane-bound form) are absolutely required for autophagosome formation (55,65-67). The autophagosome fuses with the lysosome then forming autophagolysosome, eventually resulting in the degradation of the captured proteins or organelles by lysosomal enzymes $(55,68,69)$. Once cells undergo autophagic cell death, an autophagosomal marker LC3-II increases from the conversion of LC3-I (70,71).

Our results demonstrated that the ANK-199 can induce the formation of autophagic vesicle (Fig. 4A) and acidic vesicular organelles (Fig. 4B). It also simultaneously enhances the protein level of autophagic proteins, Atg complex, beclin 1, PI3K class III and LC3-II (Fig. 5), and mRNA expression of autophagic genes Atg7, Atg12, beclin 1 and LC3-II (Fig. 6). More importantly, 3-MA, a specific inhibitor of PI3K kinase class III, can inhibit the autophagic vesicle formation induced by ANK-199 (Fig. 7). All of the above results support that ANK-199-induced cell death in CAR cells is mediated through the induction of autophagic death. This molecular signaling pathway induced by ANK-199 is summarized in Fig. 8.
However, ANK-199 treatment duration for CAR cells is $72 \mathrm{~h}$. We cannot completely rule out the possibility that apoptotic cell death or other signaling pathways can be induced by ANK-199 for longer treatment time. A series of pterostilbene derivatives have been synthesized as less toxic anticancer candidates $(30,40,72,73)$. ANK-199 is less toxic than pterostilbene (unpublished data). More importantly, ANK-199 has much less cytotoxicity in the normal oral cells (HGF and OK) than that in CAR cells (Fig. 3). This is a novel finding regarding that ANK-199 represents a promising candidate as an anti-oral cancer drug with low toxicity to normal cells. Results presented in this study show that ANK-199 may become a novel therapeutic reagent for the treatment of oral cancer in the near future (patent pending).

\section{Acknowledgements}

This study was supported by AnnCare Bio-Tech Center Inc. and a research grant from the Ministry of Health and Welfare, Executive Yuan, Taiwan (DOH101-TD-C-111-005) awarded to S.-C.K. 


\section{References}

1. Estrela JM, Ortega A, Mena S, Rodriguez ML and Asensi M: Pterostilbene: Biomedical applications. Crit Rev Clin Lab Sci 50: $65-78,2013$

2. McCormack D and McFadden D: A review of pterostilbene antioxidant activity and disease modification. Oxid Med Cell Longev 2013: 575482, 2013.

3. Cherniack EP: A berry thought-provoking idea: the potential role of plant polyphenols in the treatment of age-related cognitive disorders. Br J Nutr 108: 794-800, 2012.

4. McCormack D and McFadden D: Pterostilbene and cancer: current review. J Surg Res 173: e53-e61, 2012.

5. Mikstacka R and Ignatowicz E: Chemopreventive and chemotherapeutic effect of trans-resveratrol and its analogues in cancer. Pol Merkur Lekarski 28: 496-500, 2010 (In Polish).

6. Rimando AM and Suh N: Biological/chemopreventive activity of stilbenes and their effect on colon cancer. Planta Med 74 1635-1643, 2008

7. Li N, Ma Z, Li M, Xing Y and Hou Y: Natural potential therapeutic agents of neurodegenerative diseases from the traditional herbal medicine Chinese Dragons Blood. J Ethnopharmacol 152: 508-521, 2014

8. Paul S, Rimando AM, Lee HJ, Ji Y, Reddy BS and Suh N Anti-inflammatory action of pterostilbene is mediated through the p38 mitogen-activated protein kinase pathway in colon cancer cells. Cancer Prev Res (Phila) 2: 650-657, 2009.

9. Pan MH, Chang YH, Tsai ML, et al: Pterostilbene suppressed lipopolysaccharide-induced up-expression of iNOS and COX-2 in murine macrophages. J Agric Food Chem 56: 7502-7509, 2008.

10. Perecko T, Drabikova K, Rackova L, et al: Molecular targets of the natural antioxidant pterostilbene: effect on protein kinase $\mathrm{C}$, caspase-3 and apoptosis in human neutrophils in vitro. Neuro Endocrinol Lett 31 (Suppl) 2: 84-90, 2010.

11. Perecko T, Jancinova V, Drabikova K, Nosal R and Harmatha J: Structure-efficiency relationship in derivatives of stilbene. Comparison of resveratrol, pinosylvin and pterostilbene. Neuro Endocrinol Lett 29: 802-805, 2008

12. Rossi M, Caruso F, Antonioletti R, et al: Scavenging of hydroxyl radical by resveratrol and related natural stilbenes after hydrogen peroxide attack on DNA. Chem Biol Interact 206: $175-185,2013$

13. Acharya JD and Ghaskadbi SS: Protective effect of pterostilbene against free radical mediated oxidative damage. BMC Complement Altern Med 13: 238, 2013.

14. Rimando AM, Cuendet M, Desmarchelier C, Mehta RG Pezzuto JM and Duke SO: Cancer chemopreventive and antioxidant activities of pterostilbene, a naturally occurring analogue of resveratrol. J Agric Food Chem 50: 3453-3457, 2002.

15. Pan MH, Chang YH, Badmaev V, Nagabhushanam K and Ho CT: Pterostilbene induces apoptosis and cell cycle arrest in human gastric carcinoma cells. J Agric Food Chem 55 7777-7785, 2007.

16. Ferrer P, Asensi M, Priego S, et al: Nitric oxide mediates natural polyphenol-induced $\mathrm{Bcl}-2$ down-regulation and activation of cell death in metastatic B16 melanoma. J Biol Chem 282 2880-2890, 2007.

17. Siedlecka-Kroplewska K, Jozwik A, Boguslawski W, et al: Pterostilbene induces accumulation of autophagic vacuoles followed by cell death in HL60 human leukemia cells. J Physiol Pharmacol 64: 545-556, 2013.

18. Hsieh MJ, Lin CW, Yang SF, et al: A combination of pterostilbene with autophagy inhibitors exerts efficient apoptotic characteristics in both chemosensitive and chemoresistant lung cancer cells. Toxicol Sci 137: 65-75, 2014.

19. Kapoor S: Pterostilbene and its emerging antineoplastic effects: a prospective treatment option for systemic malignancies. Am J Surg 205: 483, 2013.

20. Tippani R, Prakhya LJ, Porika M, Sirisha K, Abbagani S and Thammidala C: Pterostilbene as a potential novel telomerase inhibitor: Molecular docking studies and its in vitro evaluation. Curr Pharm Biotechnol: Jan 12, 2014 (Epub ahead of print).

21. Li K, Dias SJ, Rimando AM, et al: Pterostilbene acts through metastasis-associated protein 1 to inhibit tumor growth, progression and metastasis in prostate cancer. PLoS One 8: e57542, 2013.

22. McCormack DE, Mannal P, McDonald D, Tighe S, Hanson J and McFadden D: Genomic analysis of pterostilbene predicts its antiproliferative effects against pancreatic cancer in vitro and in vivo. J Gastrointest Surg 16: 1136-1143, 2012.
23. Mannal PW, Alosi JA, Schneider JG, McDonald DE and McFadden DW: Pterostilbene inhibits pancreatic cancer in vitro. J Gastrointest Surg 14: 873-879, 2010.

24. Moon D, McCormack D, McDonald D and McFadden D: Pterostilbene induces mitochondrially derived apoptosis in breast cancer cells in vitro. J Surg Res 180: 208-215, 2013.

25. Pan MH, Lin YT, Lin CL, Wei CS, Ho CT and Chen WJ Suppression of heregulin-beta1/HER2-modulated invasive and aggressive phenotype of breast carcinoma by pterostilbene via inhibition of matrix metalloproteinase-9, p38 kinase cascade and Akt activation. Evid Based Complement Alternat Med 2011: 562187, 2011.

26. Yang Y, Yan X, Duan W, et al: Pterostilbene exerts antitumor activity via the Notch1 signaling pathway in human lung adenocarcinoma cells. PLoS One 8: e62652, 2013.

27. Liu Y, Wang L, Wu Y, et al: Pterostilbene exerts antitumor activity against human osteosarcoma cells by inhibiting the JAK2/STAT3 signaling pathway. Toxicology 304: 120-131, 2013.

28. Lin VC, Tsai YC, Lin JN, et al: Activation of AMPK by pterostilbene suppresses lipogenesis and cell-cycle progression in p53 positive and negative human prostate cancer cells. J Agric Food Chem 60: 6399-6407, 2012.

29. Chakraborty A, Gupta N, Ghosh K and Roy P: In vitro evaluation of the cytotoxic, anti-proliferative and anti-oxidant properties of pterostilbene isolated from Pterocarpus marsupium. Toxicol In Vitro 24: 1215-1228, 2010.

30. Roslie H, Chan KM, Rajab NF, et al: 3,5-Dibenzyloxy-4'hydroxystilbene induces early caspase- 9 activation during apoptosis in human K562 chronic myelogenous leukemia cells. J Toxicol Sci 37: 13-21, 2012.

31. Tolomeo M, Grimaudo S, Di Cristina A, et al: Pterostilbene and 3'-hydroxypterostilbene are effective apoptosis-inducing agents in MDR and BCR-ABL-expressing leukemia cells. Int J Biochem Cell Biol 37: 1709-1726, 2005.

32. Mena S, Rodriguez ML, Ponsoda X, Estrela JM, Jaattela M and Ortega AL: Pterostilbene-induced tumor cytotoxicity: a lysosomal membrane permeabilization-dependent mechanism. PLoS One 7: e44524, 2012.

33. Harun $\mathrm{Z}$ and Ghazali AR: Potential chemoprevention activity of pterostilbene by enhancing the detoxifying enzymes in the HT-29 cell line. Asian Pac J Cancer Prev 13: 6403-6407, 2012.

34. Nutakul W, Sobers HS, Qiu P, et al: Inhibitory effects of resveratrol and pterostilbene on human colon cancer cells: a side-by-side comparison. J Agric Food Chem 59: 10964-10970, 2011.

35. Huang CS, Ho CT, Tu SH, et al: Long-term ethanol exposure-induced hepatocellular carcinoma cell migration and invasion through lysyl oxidase activation are attenuated by combined treatment with pterostilbene and curcumin analogues. J Agric Food Chem 61: 4326-4335, 2013.

36. Pan MH, Chiou YS, Chen WJ, Wang JM, Badmaev V and Ho CT: Pterostilbene inhibited tumor invasion via suppressing multiple signal transduction pathways in human hepatocellular carcinoma cells. Carcinogenesis 30: 1234-1242, 2009.

37. Siedlecka-Kroplewska K, Jozwik A, Kaszubowska L, Kowalczyk A and Boguslawski W: Pterostilbene induces cell cycle arrest and apoptosis in MOLT4 human leukemia cells. Folia Histochem Cytobiol 50: 574-580, 2012

38. Chen RJ, Tsai SJ, Ho CT, et al: Chemopreventive effects of pterostilbene on urethane-induced lung carcinogenesis in mice via the inhibition of EGFR-mediated pathways and the induction of apoptosis and autophagy. J Agric Food Chem 60: 11533-11541, 2012

39. Chakraborty A, Bodipati N, Demonacos MK, Peddinti R, Ghosh K and Roy P: Long term induction by pterostilbene results in autophagy and cellular differentiation in MCF-7 cells via ROS dependent pathway. Mol Cell Endocrinol 355: 25-40, 2012.

40. Chen RJ, Ho CT and Wang YJ: Pterostilbene induces autophagy and apoptosis in sensitive and chemoresistant human bladder cancer cells. Mol Nutr Food Res 54: 1819-1832, 2010.

41. Zhang L, Cui L, Zhou G, Jing H, Guo Y and Sun W: Pterostilbene, a natural small-molecular compound, promotes cytoprotective macroautophagy in vascular endothelial cells. J Nutr Biochem 24: 903-911, 2013.

42. Riche DM, McEwen CL, Riche KD, et al: Analysis of safety from a human clinical trial with pterostilbene. J Toxicol 2013: 463595, 2013. 
43. Shetty SR, Babu S, Kumari S, Prasad R, Bhat S and Fazil KA Salivary ascorbic acid levels in betel quid chewers: A biochemical study. South Asian J Cancer 2: 142-144, 2013.

44. Arjungi KN: Areca nut: a review. Arzneimittelforschung 26: 951-956, 1976

45. Chang PY, Peng SF, Lee CY, et al: Curcumin-loaded nanoparticles induce apoptotic cell death through regulation of the function of MDR1 and reactive oxygen species in cisplatin-resistant CAR human oral cancer cells. Int J Oncol 43 : 1141-1150, 2013.

46. Lin C, Tsai SC, Tseng MT, et al: AKT serine/threonine protein kinase modulates baicalin-triggered autophagy in human bladder cancer T24 cells. Int J Oncol 42: 993-1000, 2013.

47. Tsai SC, Yang JS, Peng SF, et al: Bufalin increases sensitivity to AKT/mTOR-induced autophagic cell death in SK-HEP-1 human hepatocellular carcinoma cells. Int J Oncol 41: 1431-1442, 2012.

48. Huang WW, Tsai SC, Peng SF, et al: Kaempferol induces autophagy through AMPK and AKT signaling molecules and causes $\mathrm{G} 2 / \mathrm{M}$ arrest via downregulation of CDK1/cyclin B in SK-HEP-1 human hepatic cancer cells. Int J Oncol 42 2069-2077, 2013.

49. Huang AC, Lien JC, Lin MW, et al: Tetrandrine induces cell death in SAS human oral cancer cells through caspase activation-dependent apoptosis and LC3-I and LC3-II activation-dependent autophagy. Int J Oncol 43: 485-494, 2013.

50. Liu CY, Yang JS, Huang SM, et al: Smh-3 induces G(2)/M arrest and apoptosis through calcium-mediated endoplasmic reticulum stress and mitochondrial signaling in human hepatocellular carcinoma Hep3B cells. Oncol Rep 29: 751-762, 2013.

51. Jin Z and El-Deiry WS: Overview of cell death signaling pathways. Cancer Biol Ther 4: 139-163, 2005.

52. Jin S and White E: Role of autophagy in cancer: management of metabolic stress. Autophagy 3: 28-31, 2007.

53. Fink SL and Cookson BT: Apoptosis, pyroptosis, and necrosis: mechanistic description of dead and dying eukaryotic cells Infect Immun 73: 1907-1916, 2005.

54. Lockshin RA and Zakeri Z: Apoptosis, autophagy, and more. Int J Biochem Cell Biol 36: 2405-2419, 2004.

55. Shimizu S, Yoshida T, Tsujioka M and Arakawa S: Autophagic cell death and cancer. Int J Mol Sci 15: 3145-3153, 2014

56. Mukhopadhyay S, Panda PK, Sinha N, Das DN and Bhutia SK: Autophagy and apoptosis: where do they meet? Apoptosis 19: 555-566, 2014

57. Ma Y, Galluzzi L, Zitvogel L and Kroemer G: Autophagy and cellular immune responses. Immunity 39: 211-227, 2013.
58. Morselli E, Galluzzi L, Kepp O, et al: Anti- and pro-tumor functions of autophagy. Biochim Biophys Acta 1793: 1524-1532, 2009.

59. Li LC, Liu GD, Zhang XJ and Li YB: Autophagy, a novel target for chemotherapeutic intervention of thyroid cancer. Cancer Chemother Pharmacol 73: 439-449, 2014

60. Meschini S, Condello M, Lista P and Arancia G: Autophagy: Molecular mechanisms and their implications for anticancer therapies. Curr Cancer Drug Targets 11: 357-379, 2011.

61. Liu B, Bao JK, Yang JM and Cheng Y: Targeting autophagic pathways for cancer drug discovery. Chin J Cancer 32: 113-120, 2013.

62. Ghavami S, Shojaei S, Yeganeh B, et al: Autophagy and apoptosis dysfunction in neurodegenerative disorders. Prog Neurobiol 112: 24-49, 2014.

63. Fu LL, Cheng Y and Liu B: Beclin-1: autophagic regulator and therapeutic target in cancer. Int J Biochem Cell Biol 45: 921-924, 2013

64. Kang R, Zeh HJ, Lotze MT and Tang D: The Beclin 1 network regulates autophagy and apoptosis. Cell Death Differ 18 : 571-580, 2011

65. Parkes M: Evidence from genetics for a role of autophagy and innate immunity in IBD pathogenesis. Dig Dis 30: 330-333, 2012.

66. Martinez-Lopez N and Singh R: ATGs: Scaffolds for MAPK/ERK signaling. Autophagy 10: 535-537, 2014.

67. Tam BT and Siu PM: Autophagic cellular responses to physical exercise in skeletal muscle. Sports Med 44: 625-640, 2014

68. Jiang P and Mizushima N: Autophagy and human diseases. Cell Res 24: 69-79, 2014

69. Pottier M, Masclaux-Daubresse C, Yoshimoto K and Thomine S: Autophagy as a possible mechanism for micronutrient remobilization from leaves to seeds. Front Plant Sci 5: 11, 2014.

70. Schmeisser H, Bekisz J and Zoon KC: New function of type I IFN: Induction of autophagy. J Interferon Cytokine Res 34: 71-78, 2014.

71. Mizushima $\mathrm{N}$ and Yoshimori T: How to interpret LC3 immunoblotting. Autophagy 3: 542-545, 2007.

72. Zhang W, Sviripa V, Kril LM, et al: Fluorinated N,N-dialkylaminostilbenes for Wnt pathway inhibition and colon cancer repression. J Med Chem 54: 1288-1297, 2011.

73. Fuendjiep V, Wandji J, Tillequin F, et al: Chalconoid and stilbenoid glycosides from Guibourtia tessmanii. Phytochemistry 60: 803-806, 2002. 